\title{
REKAYASA MEDIA TANAM BERBASIS LIMBAH SERAT BUAH SAWIT UNTUK PERTUMBUHAN TANAMAN SELADA (Lactuca sativa L)
}

\section{Rosdiana $^{1 *}$, Enggar Apriyanto ${ }^{2}$, Dirgahani Putri ${ }^{1}$ dan Naswandi Nur ${ }^{1}$}

${ }^{1}$ Program Studi Agroteknologi, Fakultas Pertanian, Universitas Muhammadiyah Jakarta, Ciputat, 15419

${ }^{2}$ Program Studi Budidaya Hutan, Fakultas Pertanian, Universitas Bengkulu, Bengkulu, 38371

*E-mail : annamuchyin@gmail.com

\begin{abstract}
ABSTRAK
Keberadaan limbah pada industri kelapa sawit dalam jumal yang banyak mencapai lebih 4 ton per tahun menjadi permasalahan tersendiri. Limbah tersebut memiliki potensi sebagi media tanam. Perbaikan kualitas media diharapkan dapat menstimulasi sistem peraakaran dan pertumbuhan tanaman dengan tetap menjaga kuantitas dan kualitas selada. Tujuan penelitian adalah untuk mendapatkan kombinasi media tanam berbasis limbah serat buah sawit yang baik untuk pertumbuhan tanaman selada, menganalisis pengaruh rekayasa media tanam berbasis limbah serat buah sawit terhadap pertumbuhan dan hasil, dan menganalisis pengaruh rekayasa media tanam berbasis limbah serat buah sawit terhadap kualitas tanaman selada. Penelitian in dilaksanakan pada bulan April sampai Juli 2020 di BBI Lebak Bulus. Rancangan percobaan yang digunakan adalah metode Rancangan Kelompok Lengkap Teracak (RKLT) dengan 5 perlakuan dan 5 ulangan sekaligus sebagai blok. Lima perlakuan tersebut yaitu: komposit Tanah dan pupuk Kandang Sapi (Kontrol), Serat Buah Sawit 100\%, Limbah Serat Buah Sawit 75\% + Pupuk Kandang Sapi 25\%, Limbah Serat Buah Sawit 50\% + Pupuk Kandang Sapi 50\%, dan Limbah Serat Buah Sawit 25\% + Pupuk Kandang Sapi 75\%. Media komposit limbah serat buah sawit $75 \%$ dan pupuk kandang sapi $25 \%$ memberikan hasil terbaik pada variable jumlah daun, lebar daun, khlorofil, berat basah daun konsumsi, dan berat kering daun konsumsi.
\end{abstract}

Kata Kunci: Limbah serat buah sawit,media, pupuk kandang, selada

\section{ABSTRACT}

The waste of mesocarp fruit fiberin the palm oil industry is a problem; however it has a potensial as a plant growth. Improving the quality of the media is expected to stimulate the root system and plant growth while maintaining the quantity and quality of lettuce. The research objectives were to obtain a combination of planting media based on mesocarp palm fruit fiber waste that was good for the growth of lettuce plants, to analyze the effect of engineering planting media based on oil palm fruit fiber waste on growth and yield, and to analyze the effect of engineering planting media based on palm fruit fiber waste on the quality of lettuce plants. This research was conducted from April to July 2020 at BBI Lebak Bulus. The experimental design used was the Complete Randomized Block Design (RKLT) method 
with 5 treatments and 5 replications as a block. The five treatments are: the composite of Soil and Cow Manure (Control), 100\% Palm Fruit Fiber, 75\% Palm Fruit Fiber Waste + 25\% Cow Manure, 50\% Palm Fruit Fiber Waste + 50\% Cow Manure, and Fruit Fiber Waste Palm Oil $25 \%+$ Cow Fertilizer 75\%. Composite media of 75\% palm fruit fiber waste and $25 \%$ cow manure gave the best results on the variables of leaf number, leaf width, chlorophyll, consumption leaf wet weight, and leaf dry weight consumption.

Keywords: Mesocarp palm fruit fiber waste, media, manure, lettuce

\section{PENDAHULUAN}

Serat buah sawit merupakan bahan organik yang memiliki potensi untuk digunakan sebagai bahan media tanam (Direktorat Jenderal Perkebunan. 2014), dimana selama ini masih digunakan sebagai sumber energi pada industri sawit. Isro'i (2007) menegaskan bahwa serat buah sawit merupakan bahan organik yang dapat memperbaiki struktur tanah dengan meningkatkan kandungan bahan organik dan air tanah. Penggunaan limbah serat buah sawit sebagai media tanam belum banyak dilakukan. Penggunaan serat buah sawit telah dimanfaatkan sebagai media semai berupa blok untuk pertumbuhan semai tamanan nyamplung (Apriyanto et $a l, 2019 a$ ), ketapang (Apriyanto, et al, 2018a) dan Cemara Laut (Apriyanto et al, 2016). Serat buah sawit merupakan alternatif media tanaman yang potensial untuk aklimatisasi bibit pisang. Analisis nutrisi jaringan bibit tanaman pisang menunjukkan bahwa limbah serat buah sawit memerlukan penambahan unsur hara apabila digunakan untuk media tanam, terutama unsur $\mathrm{K}$ dan $\mathrm{P}$ (Hoe, 2014). Menurut Kamal et al. (2015) Serat buah sawit memiliki kandungan $\mathrm{N}, \mathrm{P}, \mathrm{K}, \mathrm{Mg}$, dan $\mathrm{Ca}$ yang rendah secara berurutan adalah $0.32,0.08,0.47,0.02$, dan $0.11 \%$ berat kering. Pemberian pupuk pada bibit bambang lanang (Michelia campaka) memberikan pertumbuhan bibit yang baik (Apriyanto et al, 2019b).

Pupuk kandang sapi merupakan bahan organik yang bermanfaat sebagai penyedia unsur hara makro dan mikro bagi tanaman, penggemburan tanah, memperbaiki daya serat dan tampung air tanah. Penggunaan pupuk kandang sapi diharapkan dapat mengatasi defisiensi nutrisi karena pupuk kandang dapat menyediakan unsur hara makro dan mikro bagi tanaman, dan meningkatkan daya serap air (Hartatik dan Widowati, 2010).

Perbedaan karakteristik limbah serat buah sawit dan pupuk kandang sapi memberikan peluang untuk melakukan rekayasa pembuatan media komposite berbasis limbah serat buah sawit untuk tanaman selada. Penambahan limbah serat buah sawit yang mayoritas terdiri dari serat pada media tanam memiliki potensi untuk meningkatkan porositas media tanam. Porositas media yang baik dapat menstimulasi pertumbuhan perakaran yang baik, sehingga penyerapan unsur hara dan air lebih baik. Kondisi tersebut diharapkan dapat menjadi media yang baik untuk pertumbuhan tanaman.

Media tanam yang tepat penting untuk menjaga pertumbuhan yang normal, produksi tinggi dan berkualitas. Media tanam merupakan tempat penyedia air, unsur hara, dan oksigen untuk proses fisiologi akar serta kehidupan dan aktivitas mikrobia tanah (Nursyamsi dan Tikupadang, 2014). Media tanam juga harus mampu untuk mendukung pertumbuhan tanaman dan sistem perakaran.

Keberhasilan mendapat media tanam komposit berbasis limbah serat buah sawit diharapkan dapat memberikan substitusi 
pemanfaat tanah sebagai media tanah, khususnya diperkotaan. Pemanfaatan tanah sebagai media tanam bila berlangsung terus menerus akan menyebabkan terjadinya difisiensi unsur hara. Pemanfaatan tanah tanpa memperhatikan kandungan bahan organik akan menyebabkan terjadinya kerusakan struktur tanah yang berakibat pada aerasi tanah.

Berdasarkan uraian diatas perlu dilakukan penelitian tentang rekayasa pembuatan media tanam berbasis limbah serat buah sawit untuk mendukung tanaman selada dan kualitas hasil. Tanaman selada merupakan jenis sayuran yang digemari oleh masyarakat dan berperan dalam memenuhi kebutuhan gizi manusia, karena banyak mengandung serat, vitamin dan mineral yang sangat dibutuhkan oleh tubuh manusia.

\section{METODE}

Penelitian ini dilakukan pada bulan April sampai dengan Juli 2020 di BBI Lebak Bulus. Lokasi penelitian berada pada ketinggian tanah \pm 25 meter diatas permukaan laut (m dpl). Rancangan percobaan yang digunakan adalah metode Rancangan Kelompok Lengkap Teracak (RKLT) dengan 5 perlakuan dan 5 ulangan sekaligus sebagai blok. Lima perlakuan tersebut yaitu: komposit tanah dan pupuk Kandang Sapi (Kontrol), Serat Buah Sawit 100\%, Limbah Serat Buah Sawit 75\% + Pupuk Kandang Sapi 25\%, Limbah Serat Buah Sawit 50\% + Pupuk Kandang Sapi 50\%, Limbah Serat Buah Sawit 25\% + Pupuk Kandang Sapi 75\%. Setiap satuan percobaan terdiri dari 3 tanaman sehingga jumlah seluruh tanaman yang digunakan dalam penelitian adalah sebanyak 75 tanaman.

Persemaian benih selada dilakukan di pot-tray dengan ukuran panjang $55 \mathrm{~cm}$, lebar $28 \mathrm{~cm}$ dan lubang sebanyak 50 buah dengan media kompos dicampur dengan tanah. Benih direndam dalam air hangat $\left(50^{\circ} \mathrm{C}\right)$ selama satu malam kemudian dikeringkan sebelumnya benih disemaikan. Benih ditanam sedalam lebih kurang $1 \mathrm{~cm}$ pada pot-rays.

Media tanam disiapkan satu minggu sebelum penanaman, yaitu dengan menyiapkan limbah serat buah sawit dan pupuk kandang sapi. Pembuatan media tanam komposit dilakukan dengan mencapur limbah serat buah sawit dan pupuk kandang dengan volume perbandingan 100:0\%, 75:25\%, 50:50\%, dan 25:50\%, serta composite tanah dan pupuk kandang sapi.

Penanaman dilakukan apabila bibit selada telah berumur 3-4 minggu atau sudah memiliki 4-5 helai daun. Pemilihan benih dilakukan sesuai dengan kriteria yang ditetapkan, yaitu bibit harus dalam keadaan sehat, bebas dari serangan hama dan penyakit, dan relatif seragam.

Pemupukan tanaman selada dilakukaan menggunakan pupuk standar. Pemupukan urea $1,5 \mathrm{~g}$ per polibag dan selanjutnya menggunakan pupuk cair TOP G2 dengan konsentrasi $7 \mathrm{ml} / \mathrm{L}$ dengan dosis $200 \mathrm{ml}$ per tanaman (Rosdiana dan Eghaf, 2019). Pupuk cair diberikan dengan cara menyiramkan pada media tanam. Pemberian pupuk cair TOP G2 dilakukan setiap lima hari sekali.

Penyiraman dilakukan setiap hari sampai akhir penelitian, namun demikian apabila terjadi hujan maka penyiraman tidak dilakukan. selada tumbuh normal, kemudian diulang sesuai kebutuhan. Penyiraman dilakukan sebanyak $200 \mathrm{ml}$ dengan menuangkan secara hati agar tidak terjadi limpasan.

Pemanenan selada dilakukan setelah berumur 30 hari dihitung dari setelah persamaian, dengan mencabut tanaman. 
Tanaman yang dipanen diseleksi dengan membuang bagian yang tidak bias dikonsumsi.

Parameter yang diamati yaitu jumlah daun, lebar daun, panjang daun, tinggi tanaman, klorofil daun dan biomassa. Data parameter pertumbuhan vegetatif dan produksi selada diuji menggunakan Analisis Varian dengan taraf 5\% dan. uji lanjut BNJ pada taraf 5\%.

\section{HASIL DAN PEMBAHASAN}

\section{Jumlah Daun}

Pertumbuhan tanaman selada mengalami pertumbuhan cepat setelah dipindah ke media tanam. Tanaman selada yang ditanam pada media komposit tanam limbah serat buah sawit $75 \%$ dengan pupuk kandang sapi $25 \%$ menunjukkan pertumbuhan jumlah daun lebih banyak dari pada tumbuh pada media komposit lainnya selama penelitian (Gambar 1). Analisis varian terhadap jumlah daun pada akhir penelitian menunjukkan bahwa terdapat perbedaan jumlah daun secara nyata diantara perlakuan media komposit berbasis limbah serat buah sawit. Berdasarkan hasil uji lanjut diketahui bahwa tanaman selada yang tumbuh pada media komposit limbah serat buah sawit $75 \%$ dengan pupuk kandang sapi $25 \%$ memiliki jumlah daun terbanyak $(8,3$ helai/tanaman) pada akhir pengamatan (umur 28 hari) (Gambar 2). Banyaknya jumlah daun tanaman selada yang tumbuh media komposit limbah serat buah sawit $75 \%$ dengan pupuk kandang $25 \%$ disebabkan karena media tersebut memiliki porositas yang baik dari media lain. Porositas media yang tepat dapat menahan air, menjaga kelembaban tanah dan aerasi dengan baik, sehingga pertumbuhan akar dan tanaman menjadi baik.

Media komposit dengan limbah serat buah sawit semakin sedikit jumlahnya memberikan pertumbuhan jumlah daun yang semakin sedikit. Penurunan jumlah daun tanaman selada pada media komposit limbah serat buah sawit erat kaitannya dengan porositas media. Jumlah daun tanaman selada terendah $(5,1$ helai/tanaman) didapatkan pada tanaman selada yang tumbuh pada media serat buah sawit $100 \%$. Hal ini disebabkan media serat buah sawit memiliki kandungan $\mathrm{N}$ yang rendah oleh karena proses dekomposisi oleh miikroorganisme (Hoe, 2014). Kondisi terebut disebabkan porositas media serat buah sawit terlalu tinggi, sehingga kemampuan untuk menahan air kurang. Pertumbuhan jumlah daun tanaman selada yang sedikit juga disebabkan karena ketersediaan unsur pada limbah serat buah sawit tidak mencukupi untuk pertumbuhan daun tanaman selada. 


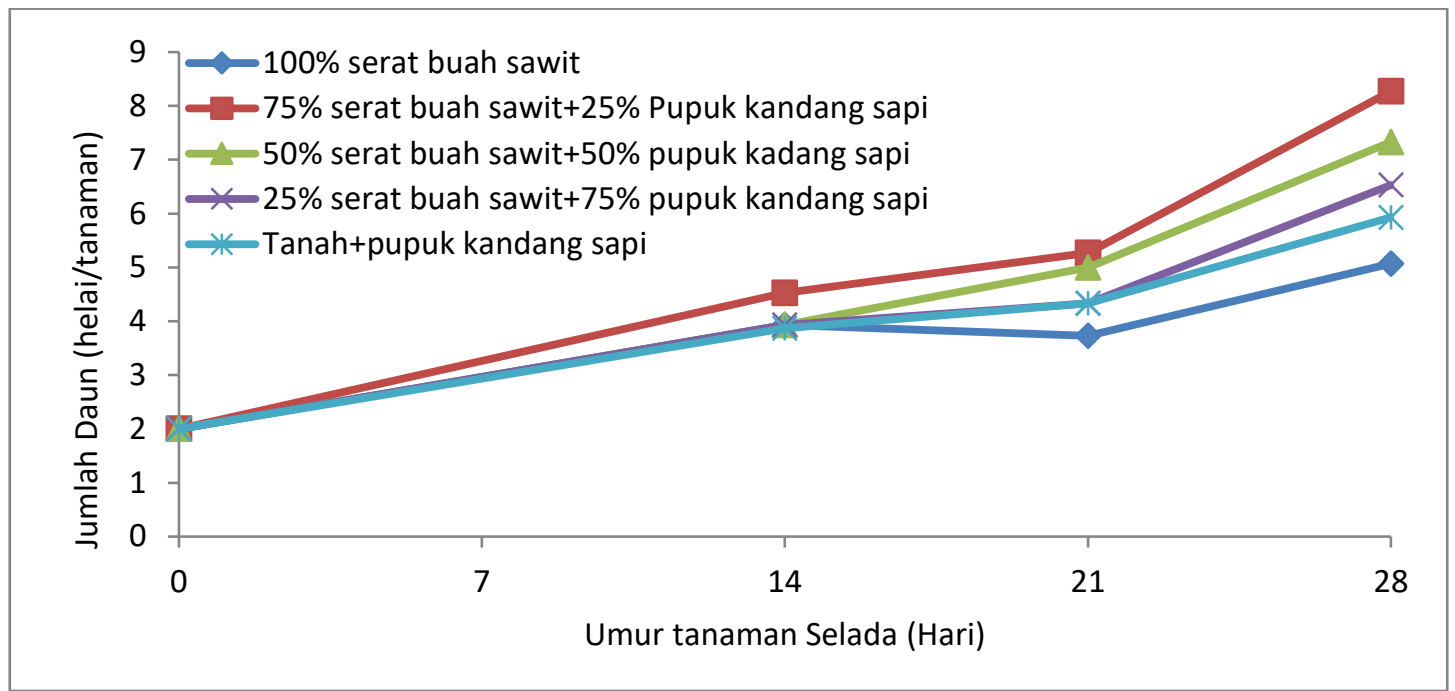

Gambar 1. Pertumbuhan jumlah daun tanaman selada yang terbentuk pada berbagai media komposit berbasis limbah serat buah sawit selama penelitian.

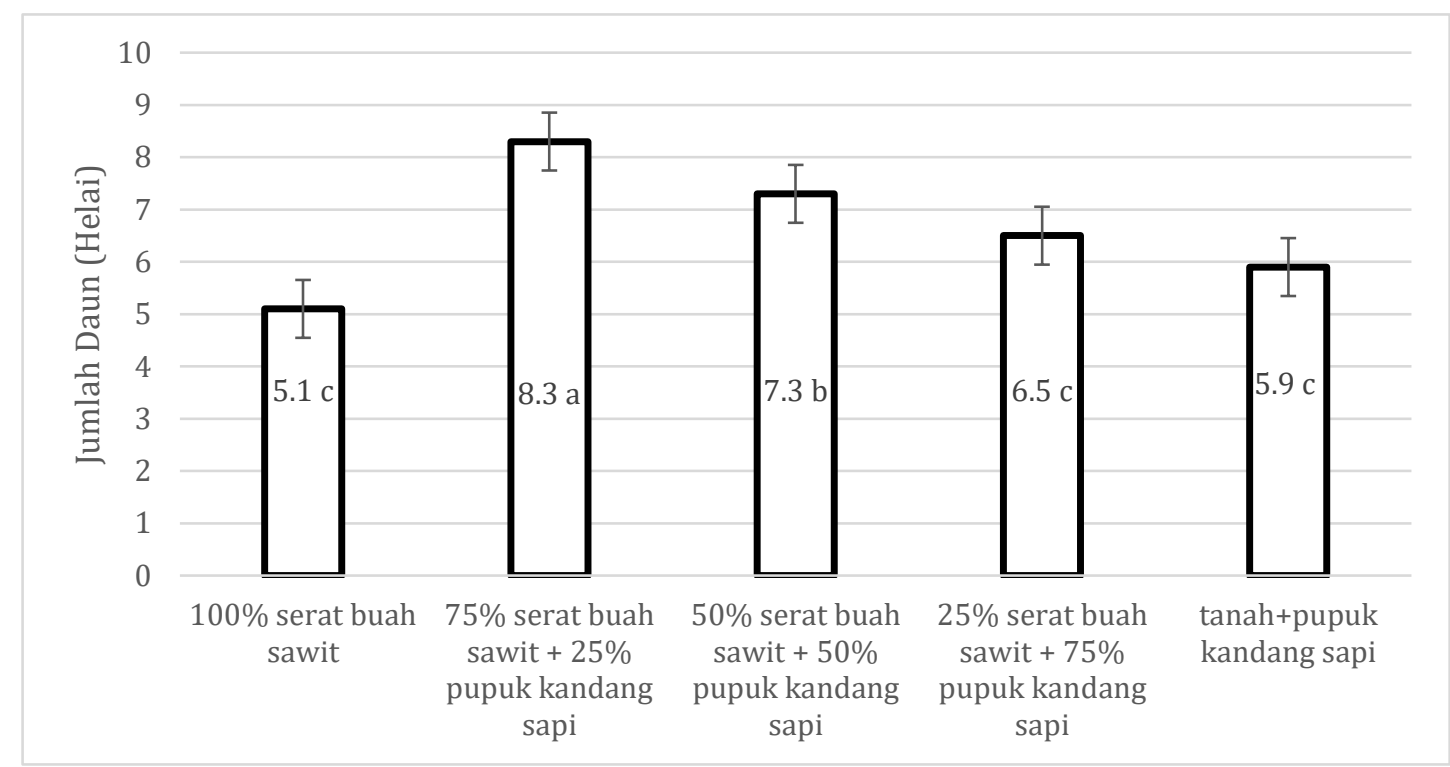

Gambar 2. Jumlah daun tanaman selada yang terbentuk pada berbagai media komposit berbasis limbah serat buah sawit pada akhir pengamatan (umur 28 hari).

\section{Lebar dan Panjang Daun}

Pertumbuhan lebar daun terus mengalami peningkatan dalam ukurannya dengan bertambahnya umur tanaman selada pada media tanam yang berbeda. Hasil pengukuran lebar daun tanaman selada selama penelitian disajikan pada Gambar 3. Analisis data lebar daun tanaman selada yang tumbuh pada media komposit berbasis limbah serat buah sawit menunjukkan adanya perbedaan yang nyata diantara perlakuan. 


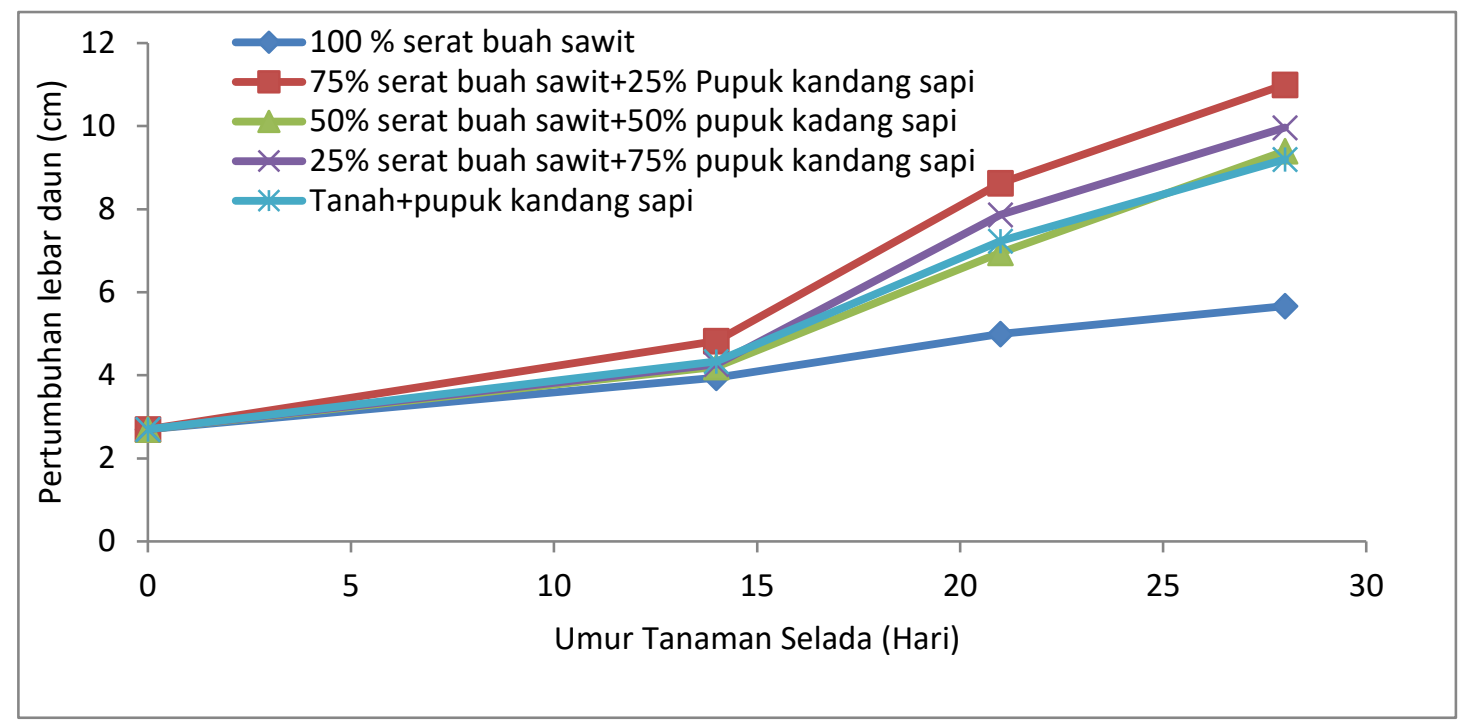

Gambar 3. Grafik pertumbuhan lebar daun tanaman selada yang terbentuk pada berbagai media komposit berbasis limbah serat buah sawit selama penelitian.

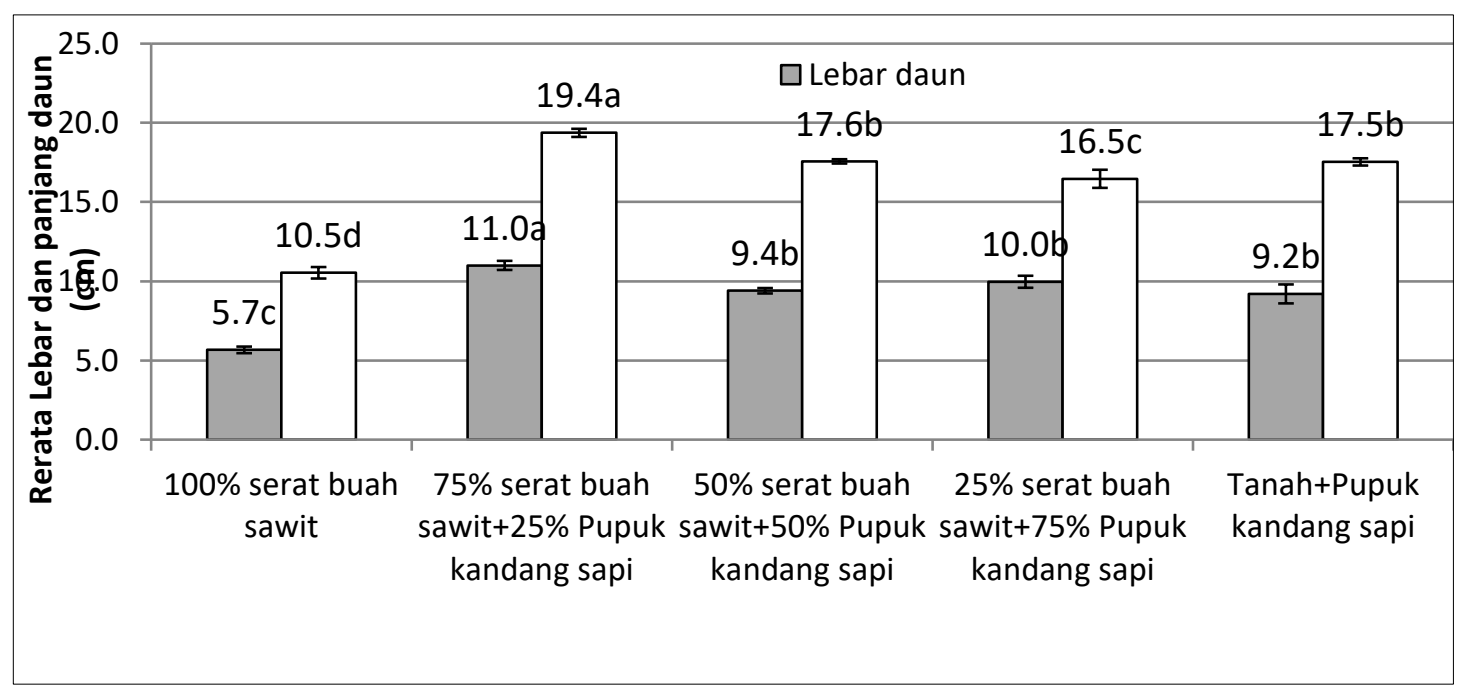

Gambar 4. Rerata lebar dan panjang daun tanaman selada yang terbentuk pada berbagai media komposit berbasis limbah serat buah sawit pada akhir pengamatan (umur 28 hari).

Berdasarkan hasil uji lanjut pada akhir penelitan diketahui bahwa lebar daun tanaman selada terlebar (11 helai/tanaman) terjadi pada tanaman selada yang ditanam pada media komposit $75 \%$ libah serat buah sawit dengan $25 \%$ pupuk kandang (Gambar 4). Lebar daun tanaman selada yang tumbuh pada media komposit limbah serat buah sawit 50, 25 dan 0\% yaitu secara berurutan 9.4, 10.0, dan $9.2 \mathrm{~cm}$. Ketiga perlakuan tersebut tidak menunjukkan perbedaan dalam ukuran lebar daun tanaman selada.

Pemanfaatan limbah serat buah sawit sebagai media komposit untuk tanaman selada memberikan pertumbuhan yang baik. Penambahan pupuk kandang sapi dapat memberikan substitusi unsur hara yang tidak terdapat pada limbah serat buah 
sawit. Penggunaan kompos dan limbah serat buah sawit memberikan nutrisi yang cukup untuk pertumbuhan pada bibit pisang dan menghasilkan pertumbuhan meninggi yang terbaik (Hoe, 2014). Analisis varian terhadap panjang daun selada pada akhir penelitian menunjukkan bahwa terdapat perbedaan yang sangat nyata diantara media komposit berbasis limbah serat buah sawit. Berdasarkan hasil uji lanjut diketahu bahwa media komposit $75 \%$ limbah serat buah sawit $+25 \%$ pupuk kandang memberikan pertumbuhan panjang daun tertinggi.

\section{Tinggi Tanaman}

Pertumbuhan tinggi tanaman selada selam penelitan disajikan pada Gambar 5. Analisis varian menunjukkan adanya beda nyata diantara perlakuan. Pertumbuhan tinggi tanaman selada tertinggi pada perlakuan 25\% serat buah sawit dan $75 \%$ pupuk kandang sapi (Gambar 6).

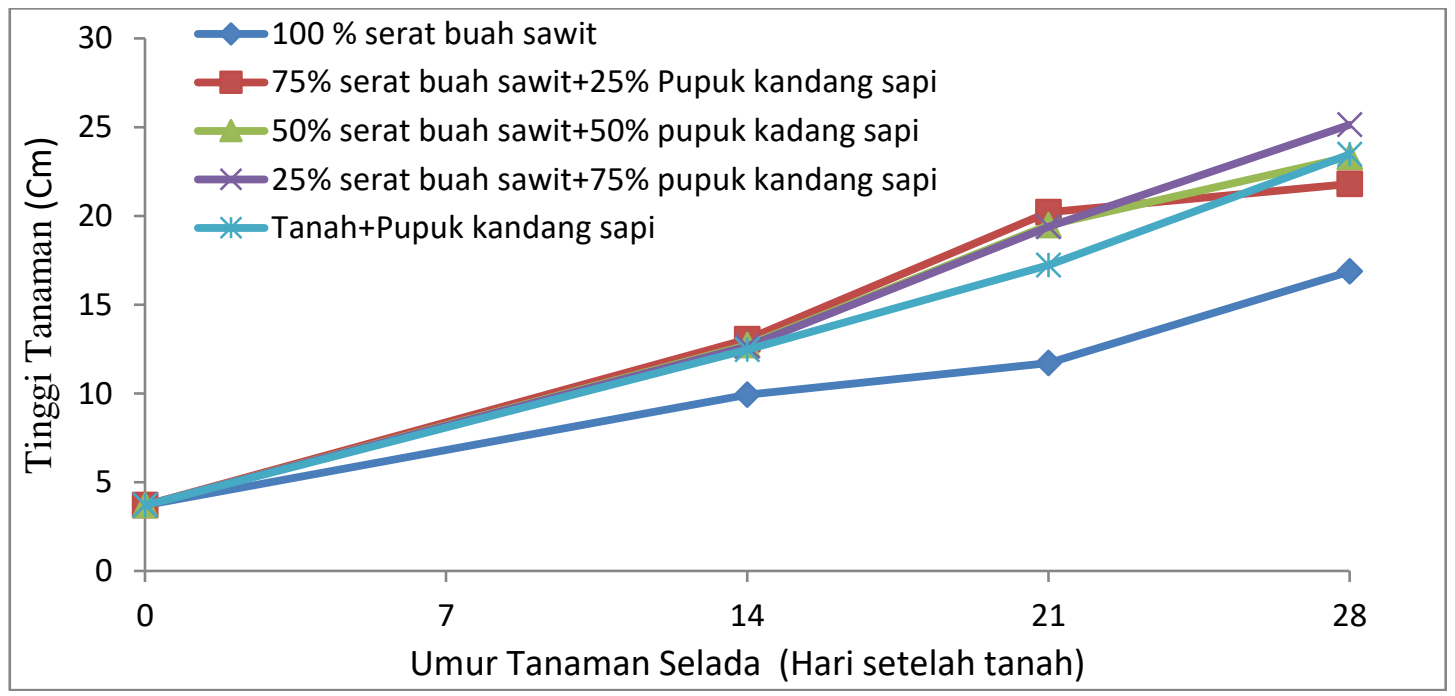

Gambar 5. Grafik pertumbuhan panjang daun tanaman selada yang terbentuk pada berbagai media komposit berbasis limbah serat buah sawit selama penelitian. 


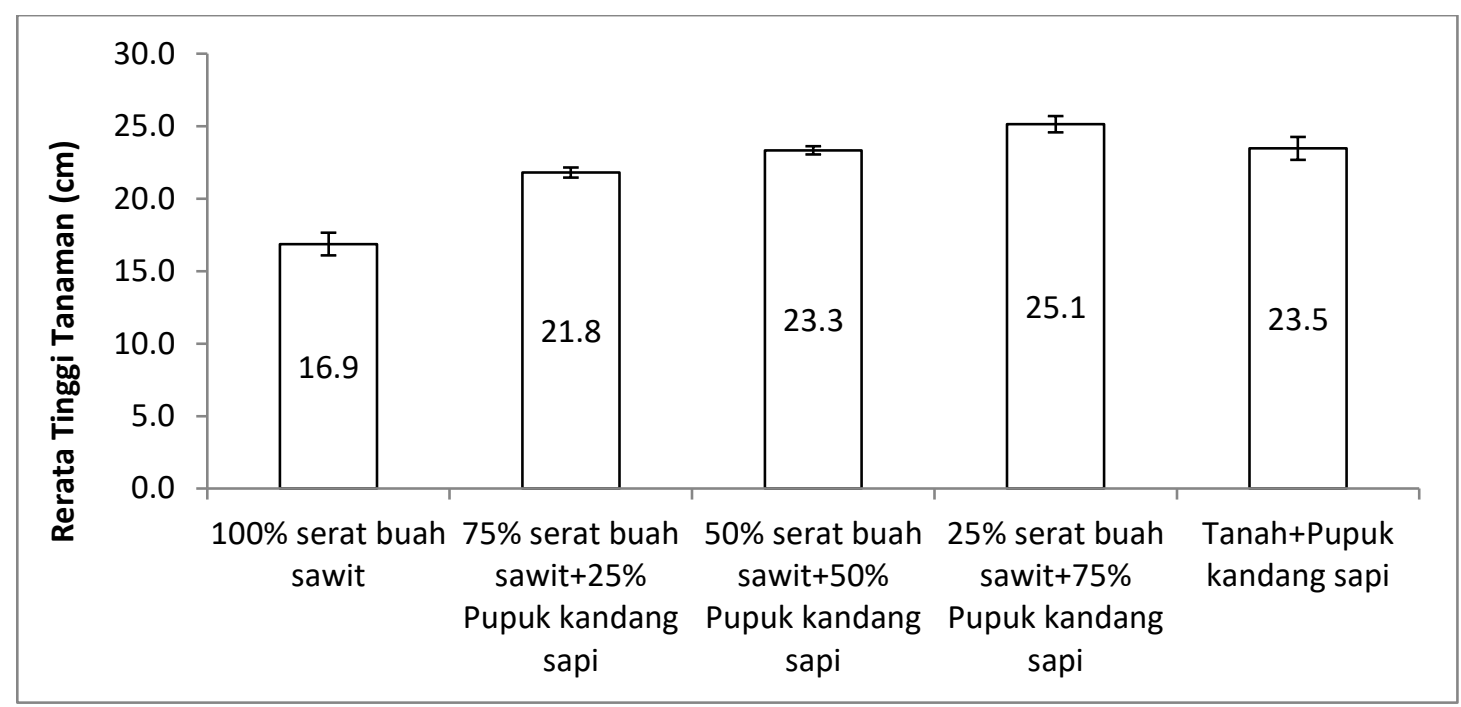

Gambar 6. Rata-rata tinggi tanaman selada yang terbentuk pada berbagai media komposit berbasis limbah serat buah sawit pada akhir pengamatan (umur 28 hari).

Rata-rata tinggi tanaman pada umur 28 hari menunjukkan bahwa perlakuan $25 \%$ serat buah sawit $+75 \%$ pupuk kandang sapi memiliki tinggi tanaman tertinggi yaitu $25,1 \mathrm{~cm}$. Hal ini diduga karena kombinasi tersebut memiliki hara nitrogen terbaik. Nitrogen mempunyai peranan utama untuk merangsang pertumbuhan secara keseluruhan dan khususnya pertumbuhan batang yang dapat memacu pertumbuhan tinggi tanaman (Rambe dan Yunus, 2013). Ketersediaan unsur hara yang dapat diserap tanaman merupakan salah satu faktor yang dapat mempengaruhi tingkat pertumbuhan dan perkembangan tanaman (Novizan, 2005).

\section{Klorofil Daun}

Klorofil merupakan kandungan daun yang memegang penting dalam proses fotosintesis dalam menghasilkan karbohidrat. Daun yang memiliki klorofil tinggi memberikan indikasi kualitas daun yang baik sebagai sumber pangan. Hasil pengukuran klorofil daun tanaman selada dengan chlorofil meter pada akhir pengamatan (umur 28 hari) disajikan dalam
Gambar 7. Berdasarkan hasil analisis terhadap klorofil diketahui bahwa ada perbedaan yang nyata klorofil daun tanaman selada yang tumbuh pada berbagai media komposit berbasis limbah sawit. Uji lanjut menunjukkan bahwa klorofil daun tanaman selada yang tumbuh pada media $75 \%$ serat buah sawit $+25 \%$ pupuk kandang memberikan nilai klorofil tertinggi. Daun dengan kandungan klorofil tinggi memiliki potensi sebagai sumber suplemen makanan (Kurniawan et al. 2010), klororfil daun tanaman selada yang tumbuh pada $25 \%$ serat buah sawit $+75 \%$ pupuk kandang sapi dan Tanah + pupuk kandang memberikan nilai klorofil tidak berbeda nyata. Keduanya perlakuan tersebut memiliki klorofil lebih tinggi dari perlakuan media komposit $100 \%$ serat buah sawit dan $50 \%$ serat buah sawit + $50 \%$ pupuk kandang. Klorofil daun selada tertinggi pada media komposte $100 \%$ serat buah sawit $+25 \%$ pupuk kandang menunjukkan bahwa media tersebut memiliki sifat fisik dan kimia yang cukup untuk mendukung pertumbuhan tanaman selada. 


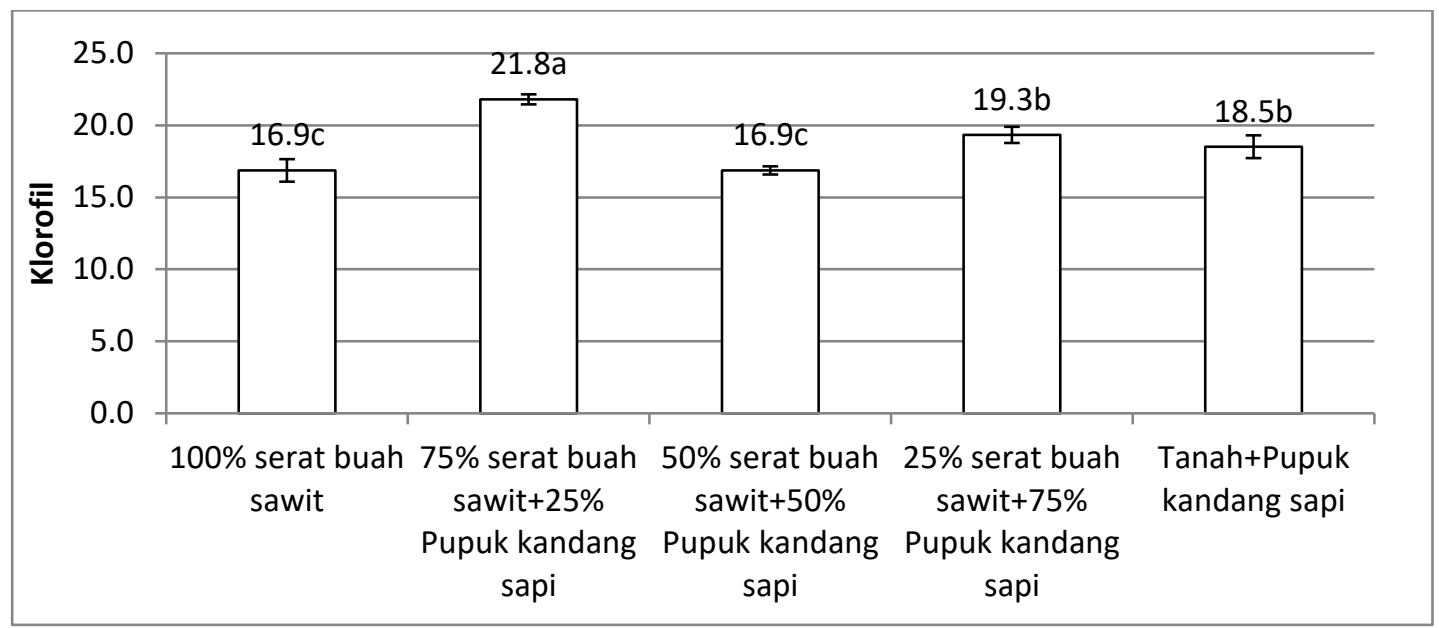

Gambar 7. Rata-rata klorofil daun tanaman selada yang terbentuk pada berbagai media komposit berbasis limbah serat buah sawit pada akhir pengamatan (umur 28 hari).

\section{Biomasa}

Analisis varian terhadap berat basah daun terkonsumsi menunjukkan bahwa media tanam dengan komposisi berbeda memberikan perbedaan yang nyata (Tabel 1). Hasil uji lanjut Beda Nyata Jujur dengan taraf kepercayaan 5\% menunjukkan media tanam komposit limbah serat buah sawit 75\% dengan pupuk kandang sapi $25 \%$ menghasilkan berat basah daun terberat $(20,12 \pm 5,964$ $\mathrm{g} /$ tanaman). Tingginya berat basah daun selada yang tumbuh pada media komposit limbah serat buah sawit 75\% dengan pupuk kadang sapi $25 \%$ disebabkan oleh karena media tersebut memiliki porositas yang lebih baik dan ketersediaan unsur hara yang cukup. Kemampuan limbah serat buah sawit untuk menjerat air memungkinkan media komposit tersebut dapat menjaga kebutuhan akan air untuk tanaman selada. Pemanfaatan serat pada media sebagai media tanam memberikan pertumbuhan bibit yang baik (Hoe, 2014; Durahim dan Hendromono, 2006). Media tanam limbah serat buah sawit 100\% menghasilkan berat basah daun terkecil $\left(3.10 \pm 1.502 \mathrm{~g} \mathrm{tanaman}{ }^{-1}\right)$. Hal ini dikarenakan media tanam serat limbah sawit terlalu porus, yang menyebabkan air dan nutrisi yang diberikan cepat mengalami pelindihan. Tingginya pelindihan dapat menyebabkan tidak tersedianya air dan nutrisi yang cukup untuk tanaman selada.

Hasil analisis terhadap berat kering daun terkonsumsi juga menunjukkan beda nyata diantara perlakuan media tanam yang diujikan. Uji lanjut dengan Uji Beda Nyata Jujur pada taraf kepercayaan 5\% menunjukkan media komposit limbah serat buah sawit $75 \%$ dengan pupuk kandang sapi $25 \%$ memberikan nilai berat kering daun terkonsumsi tertinggi $(0.91 \pm 0.279 \mathrm{~g}$ tanaman $\left.^{-1}\right)$. Penggunaan kombinasi limbah serat buat dengan tanah memberikan pertumbuhan bibit dengan baik. Penggunaan komposit serat buah sawit $50 \%$ dengan tanah 50\% memberikan pertumbuhan semai Eboni terbaik (Durahim dan Hendromono, 2006). 
Tabel 1. Berat basah dan berat kering tanaman selada pada akhir pengamatan

\begin{tabular}{lccccc}
\multirow{2}{*}{ Perlakuan } & \multicolumn{2}{c}{ Berat Basah $(\mathrm{g} / \mathrm{Tnm})$} & \multicolumn{3}{c}{ Berat Kering $(\mathrm{g} / \mathrm{Tnm})$} \\
\cline { 2 - 6 } & $\begin{array}{c}\text { Daun } \\
\text { (terkonsumsi) }\end{array}$ & Akar & $\begin{array}{c}\text { Daun } \\
\text { (terkonsumsi) }\end{array}$ & Akar & Batang \\
\hline P100 & $3.10 \pm 1.502 \mathrm{c}$ & $0.24 \pm 0.178$ & $0.21 \pm 0.093 \mathrm{~d}$ & $0.05 \pm 0.014$ & $0.031 \pm 0.015$ \\
\hline P75 & $20.12 \pm 5.964 \mathrm{a}$ & $0.24 \pm 0.084$ & $0.91 \pm 0.279 \mathrm{a}$ & $0.09 \pm 0.014$ & $0.044 \pm 0.031$ \\
\hline P50 & $12.85 \pm 3.713 \mathrm{~b}$ & $0.14 \pm 0.056$ & $0.54 \pm 0.139 \mathrm{c}$ & $0.05 \pm 0.015$ & $0.038 \pm 0.030$ \\
\hline P25 & $14.14 \pm 8.530 \mathrm{~b}$ & $0.14 \pm 0.097$ & $0.68 \pm 0.379 \mathrm{~b}$ & $0.05 \pm 0.025$ & $0.043 \pm 0.041$ \\
\hline P0 & $14.19 \pm 8.207 \mathrm{~b}$ & $0.16 \pm 0.064$ & $0.57 \pm 0.302 \mathrm{bc}$ & $0.05 \pm 0.025$ & $0.111 \pm 0.081$ \\
\hline
\end{tabular}

Keterangan: Angka-angka pada kolom dan baris yang sama yang diikuti oleh huruf yang sama tidak berbeda nyata pada taraf uji Beda Nyata Jujur (BNJ) $5 \%$.

\section{SIMPULAN}

Penggunaan media komposit berbasis limbah serat buah sawit memberikan pengaruh yang baik terhadap pertumbuhan tanaman selada. Media komposit $75 \%$ limbah serat buah sawit dengan $25 \%$ pupuk kandang memberikan pertumbuhan dan produksi tanaman selada yang paling baik.

\section{DAFTAR PUSTAKA}

Apriyanto E, Sudjatmiko S, Susatya A, dan Depri. 2018b. The potency of oil palm fruit fiber as growth media for ketapang (Terminalia catappa) seedling. International Journal of Agriculture. Forestry and Plantation. Vol. 7 (Dec.). 73-78.

Apriyanto E., Nugroho P.B.A., and Saputra L. 2016. The growth of Casuarina equisetiofolia seedling On various growth media densities of oil palm fruit fiber. Paper presented at The 2nd International Multidiscplinary Conference (2nd IMC). December. 242016. University Of Muhammadiyah Jakarta. Indonesia of oil palm fruit fiber as growth media for ketapang (Terminalia catappa) seedling.

Apriyanto E., Sudjatmiko S., Susatya A., Putranto B A N and Aulia E. 2018a. The potency of oil palm fruit fiber as growth media for ketapang (Terminalia catappa) seedling. International
Journal of Agriculture. Forestry and Plantation. Vol 7 Dec pp 73-78.

Apriyanto E., Vera T., Sigit S., and Agus S. 2019b. The effect of oil palm mesocarp fruit fibers waste block as ameliorant on the growth of nyamplung (Calophyllum innophyllum) in the sandy soil. International Conference on Sustainable Agriculture and Biosystem 2019 Faculty of Agricultural Technology - Andalas University Campus Limau Manis Padang. West Sumatra. Indonesia Website: http://conference.fateta.unand.ac.id/ics ab2019

Apriyanto. E; Wahyu. H. and Sudjatmiko S. 2019a. The Growth of Nyamplung (Calophyllum innophyllum) with Different Planting Techniques Using Oil Palm Fruits Mesocarp Fibers Waste In Sandy Soil. Disampaikan pada International Conference on Agriculture (ICA-2019). Di selenggarakan tanggal 30-11-2019 oleh Universitas Pembangunan Surabaya (UPN) di Rungkut. Surabaya. Jawa Timur. Indonesia

Direktorat Jenderal Perkebunan. 2014. Statistik Perkebunan Indonesia: Kelapa sawit 2013-2015. Jakarta. Growth. Prentice-Hall. Inc. New Jersey.

Durahim dan Hendromono. 2006. Pengaruh media dan pupuk NPK terhadap pertumbuhan dan mutu bibit eboni. Jurnal Penelitian Hutan dan 
Konservasi Alam (3) (1) : 9-17. Pusat Penelitian dan Pengembangan Hutan dan Konservasi Alam. Bogor.

Hartatik W. dan L. R Widowati. 2010. Pupuk Kandang. http://www.Balittanah litbang.deptan.go.id

Hoe. T.K. 2014. Utilization of oil palm fruits mesocarp fibres waste as growing media for banana tissue culture seedling in Malaysia. Journal of Advanced Agricultural Technologies Vol.1.No.1:52-55p

Isro'i. 2007. Pengomposan Limbah Kakao. Makalah Pelatihan TOT Budidaya Kopi dan Kakao. Pusat Penelitian Kopi dan Kakao Jember. 2530 Juni 2007

Kamal N. 2014. Karakterisasi dan potensi pemanfaatan limbah sawit. http://lib.itenas.ac.id/kti/wpcontent/uploads/2014/04/JURNALNetty-Kamal-ED-15.pdf

Kurniawan M. Munifatul I. dan Yulita N. 2010. Kandungan Klorofil, Karotenoid, dan Vitamin C pada Beberapa Spesies Tumbuhan Akuatik. Buletin Anatomi dan Fisiologi Vol. XVIII. No. 1. 28-40

Novizan. 2005. Pemupukan yang efektif. Agromedia Pustaka. Jakarta.

Nursyamsi dan Tikupadang. 2014. Pengaruh komposisi biopotting terhadap pertumbuhan Sengon laut (Paraserianthes falcataria 1 . Nietsen) di persemaian (the effect of biopotting composition on sengon laut (Paraserianthes falcataria L. Nietsen) in the nursery). Jurnal Penelitian Kehutanan Wallacea. 3(1):65-73

Rambe dan Muhammad Yunus. 2013. Penggunaan Pupuk Kandang Ayam dan Pupuk Urea Terhadap Pertumbuhan dan Hasil Tanaman Selada (Lactuca sativa L.) di Media Gambut. Fak. Pertanian Univ. Islam Negeri Sultan Syarif Kasim Riau Pekanbaru. 
Jurnal Agrosains dan Teknologi Volume 5 Nomor 2 Desember 2020

p-ISSN 2528-020 1

website : jurnal.umj.ac.id/index.php/ftan

e-ISSN 2528-3278 